\title{
Uma viagem transnacional do feminismo: outra lente para a história
}

\author{
How Feminism Travels across \\ Borders - The Making of Our \\ Bodies, Ourselves.
}

DAVIS, Kathy.

Durham and London: Duke University Press, 2007.

A historiadora holandesa Kathy Davis compartilha no livro How Feminism Travels across Borders, de maneira autêntica e singular, os resultados de uma ampla pesquisa que buscou abordar a circulação das teorias feministas sobre a saúde da mulher, com a obra que se tornou best seller dentro e fora dos Estados Unidos na década de 1970 e manteve essa posição até o final dos anos 1980, Our Bodies, Ourselves.

Davis, que é pesquisadora sênior do Research Institute for History and Culture na Utrecht University, na Holanda, analisa essa obra estadunidense de maneira crítica e com um distanciamento necessário. Sua proposta foi observar o modo como o livro "viajou" por diversos países - foi traduzido para mais de 30 idiomas - e as implicações dessa viagem na maneira de se pensarem o conhecimento feminista e as políticas de saúde em um mundo "globalizado". Ela percebe a produção e a recepção do livro como uma teoria que transita entre as especificidades de um contexto mundial e nos conta que Our Bodies, Ourselves surgiu da compilação das discussões sobre "as mulheres e seus corpos" em encontros pontuais que aconteceram em diversos países, no final dos anos 1960, promovidos pelo grupo Boston Women's Health Book Records - BWHBC. O resultado foi um manual com relatos de experiências pessoais e informações úteis a respeito da saúde das mulheres.
Editado em 1970, Our Bodies, Ourselves passou por diversas traduções e reedições, a última em 2005. De acordo com a autora, nesse ano já havia vendido mais de quatro milhões de exemplares (quatro vezes mais do que $O$ segundo sexo, de Simone de Beauvoir), tornando-se uma obra de popularidade única na história do feminismo. Sua função principal, além do esclarecimento, teria sido a de desafiar os dogmas médicos sobre os corpos das mulheres, sendo denominado a "bíblia da saúde das mulheres".

A interpretação de Davis é apresentada em três partes, que dimensionam a elaboração da obra e suas viagens a outras localidades; as políticas feministas de conhecimento, com o empoderamento que elas trazem; e a política transnacional do corpo, com uma crítica aos padrões ditados por modelos médicos pretensamente hegemônicos, mas também a um modelo de feminismo considerado imperialista.

Por meio de entrevistas, com o apoio das ferramentas da história oral e no campo da teoria feminista transnacional, a pesquisa foi realizada principalmente nos Estados Unidos, contando com depoimentos da maioria das autoras do livro, que formavam na época (1969) o grupo de Boston. Além disso, Kathy Davis promoveu encontros de discussão com um grupo de tradutoras da obra para os mais diversos idiomas. Assim, pôde analisar de que maneira o livro foi adaptado às necessidades específicas de cada país ou de cada região aonde chegava. Certamente não era possível prever uma aceitação das ideias que circulavam entre as feministas estadunidenses naquele momento por mulheres situadas na Ásia ou no Oriente Médio, lugares aonde a obra também chegou, principalmente no que se referia às questões sobre aborto e direitos reprodutivos.

Davis informa que o Brasil é um dos países que aguarda a tradução e que a adaptação mais próxima é a versão feita na Espanha, Nuestros cuerpos, nuestras vidas, já que a versão latino-americana acabou ficando incompleta 
e não chegou a ser editada devido a conflitos regionais. As editoras e as tradutoras locais não achavam possível pensar uma unidade do contexto latino-americano, alegando que não seria o mesmo traduzir o livro para uma mulher nicaraguense da periferia ou para uma mulher da classe média argentina. As especificidades nas traduções que a autora aponta nos sugerem que a distância cultural faz toda diferença para a leitura e a compreensão da obra, moldada mas também subvertida em cada situação.

Um aspecto interessante da análise proposta pelo livro How Feminism Travels across Borders é a compreensão de como as políticas de localização puderam gerar diferentes visões sobre a história, o conhecimento e as práticas feministas, e as possibilidades e os limites de alianças políticas entre mulheres de dentro e de fora dos Estados Unidos, país tido como missionário das ideias imperialistas. Com isso, aparece a crítica a Robin Morgan, que idealizou e organizou o livro Sisterhood is Global. ${ }^{1} \mathrm{em}$ 1984, com a proposta de alcançar um "feminismo global". Davis contrapõe a essa perspectiva a ênfase na localização, que faz um movimento para fora das histórias lineares do feminismo no intuito de explorar como ele emerge, muda, viaja e se traduz em diferentes contextos espaciais e temporais. Dessa forma, a autora busca tornar visível o significado histórico do livro, tomando como paradigma de sua crítica o que chamou uma "história transnacional", situada no contexto de um mundo em processo veloz de globalização.

O historiador e sociólogo francês Roger Chartier é peça importante nessa discussão, trazendo a noção da leitura como apropriação da obra original e todas as possibilidades que essa troca direta pode proporcionar. Para ele, é necessário que se reconheça a pluralidade das leituras possíveis de um mesmo texto, em função das disposições individuais, culturais e sociais de cada um dos leitores. ${ }^{2}$

No caso de Our Bodies, Ourselves, o livro pôde fazer-se e refazer-se seguindo as indicações das próprias leitoras, que escreviam para as autoras permitindo a elas acrescentar ou reelaborar informações e narrativas de experiências. Portanto, mulheres lésbicas, idosas, portadoras de deficiência ou com outras necessidades específicas foram sendo incluídas nas novas edições. Kathy Davis aponta a obra como um elemento móvel, um "documento vivo" atuando na constituição de sujeitos feministas em diferentes localizações, não como um material de consumo.
Outras autoras têm construído reflexões sobre as circulações e as viagens das teorias, buscando compreender as dinâmicas do feminismo transnacional. No campo dos estudos pós-coloniais encontramos o trabalho de Cláudia de Lima Costa, com a proposta similar à de Davis de se olhar para o feminismo como uma teoria que viaja, dentro do que esta última chamou de "projeto epistemológico feminista". Costa propõe pensarmos sobre a circulação de teorias dentro do campo feminista, levando em conta o trânsito entre o hemisfério norte, tradicionalmente visto como emanador, e o hemisfério sul das Américas, que seria o receptor das teorias. $^{3}$

Como contraponto a esse argumento, Adriana Piscitelli fala sobre a hierarquização evidenciada por ele e mostra que é preciso ter atenção quanto à apropriação de concepções feministas fora do âmbito em que elas se desenvolvem, pois as referências externas podem obscurecer a compreensão de como operam as práticas locais. ${ }^{4}$

Cláudia de Lima Costa aponta a tradução cultural como um espaço privilegiado para se elaborarem análises críticas sobre a política de representação e as assimetrias entre linguagens no deslocamento das teorias feministas por espaços geopolíticos diferentes. ${ }^{5}$

María Luisa Femenías e Nelly Richard colaboram com esse debate, valorizando as reflexões produzidas pelas feministas em âmbito local e a não subordinação às ideias que chegam por meio dos materiais estrangeiros. Para Femenías, o "lugar de apropriação" que resulta do traslado das teorias fratura, de maneira decisiva, o discurso original, permitindo uma revalorização e uma ressignificação contextualizada. ${ }^{\circ}$

Nelly Richard também discute a questão da apropriação das teorias dos chamados países do "centro" por aqueles considerados de "periferia". Para ela, as operações de códigos das práticas subalternas reinterpretam e criticam hibridamente, a partir do seu interior, os signos da cultura dominante. A autora ataca e desconstrói os argumentos das feministas dos países do norte, que apontam para a divisão entre a teoria produzida por elas e a experiência compartilhada pelas latino-americanas. De acordo com Richard, muitas teóricas escrevem a partir de elaborações formuladas por mulheres latino-americanas, consideradas incapazes para a produção teórica.?

Kathy Davis, com sua interpretação sobre o fazer-se do livro Our Bodies, Ourselves, situa- 
se em confluência com a crítica suscitada por esse debate e termina o livro com reflexões a respeito da postura das feministas estadunidenses, que veem o feminismo como um produto de seu país. A autora contrapõe o que chamou de declínio da "segunda onda branca" com a ascensão de um feminismo multirracial. Para ela, o livro mostra que o feminismo não está limitado aos Estados Unidos e ganha mais força fora de lá, enriquecido pela multiplicidade de contextos.

Davis apresenta uma pesquisa de fôlego e relevância para os campos dos estudos feministas, da teoria feminista transnacional, da história cultural e, também, dos estudos póscoloniais (que recebem da autora uma crítica importante por reforçar a ênfase nas sociedades do chamado Primeiro Mundo).

O título How Feminism Travels across Borders - The Naking of Our Bodies, Ourselves nos faz pensar sobre o tipo de fronteira (border) ao qual a autora se refere, uma vez que as fronteiras territoriais geográficas estão sendo cada vez mais apagadas pelos movimentos transnacionais, como é o feminismo, ele próprio situado num espaço "entre-fronteiras", a princípio marginalizado, atualmente problematizado com interesse por diversos campos, dentro e fora da academia. De qualquer maneira, o livro de Kathy Davis abre outras perspectivas para pensarmos a história do feminismo de modo mais amplo e torna-se leitura indispensável para quem se interessa por quaisquer dos campos mencionados.

\section{Notas}

1 Robin MORGAN, 1996.

${ }^{2}$ Roger CHARTIER, 2001.

${ }^{3}$ Cláudia de Lima COSTA, 2004.

${ }^{4}$ Adriana PISCITELLI, 2005.
${ }^{5}$ COSTA, 2003.

${ }^{6}$ María Luisa FEMENÍAS, 2006.

${ }^{7}$ Nelly RICHARD, 2003.

\section{Referências bibliográficas}

CHARTIER, Roger. "Do livro à leitura". In: (Org.). Práticas da leitura. Tradução de Cristiane Nascimento. São Paulo: Estação Liberdade, 2001. p. 77-105.

COSTA, Cláudia de Lima. "As publicações feministas e a política transnacional da tradução: reflexões do campo". Revista Estudos Feministas, Florianópolis: CFH/CCE/UFSC, v. 11, n. 1, p. 254-264, 2003.

. "Feminismo, tradução, transnacionalismo". In: COSTA, Cláudia de Lima; SCHMIDI, Simone Pereira (Org.). Poéticas e políticas feministas. Florianópolis: Editora Mulheres, 2004. p. 187196.

FEMENÍAS, María Luisa. "Afirmación identitaria, localización y feminismo mestizo". In: (Comp.). Feminismos de París a La Plata. Buenos Aires: Catálogos, 2006. p. 97-125.

MORGAN, Robin (Ed.). Sisterhood is Global - The International Women's Movement Anthology (1984). 2. ed. New York: The Feminist Press at The City University of New York, 1996.

PISCITELLI, Adriana. "A viagem das teorias no embate entre práticas acadêmicas, feminismos globais e ativismos locais". In: MORAES, Maria Lygia Quartim de (Org.). Gênero nas fronteiras do sul. Campinas: Pagu; UNICAMP, 2005. p. 143-163.

RICHARD, Nelly. Intervenções críticas: arte, cultura, gênero e política. Belo Horizonte: UFMG, 2003.

Ana Maria Veiga

Universidade Federal de Santa Catarina 